\title{
Thai Persuasive Discourse: A Systemic Functional Approach to an Analysis of Amulet Advertisements
}

\author{
Pattama Patpong \\ Mahidol University (Thailand) \\ lcppa@mahidol.ac.th
}

\begin{abstract}
Advertisements, as a distinct register or text type, are characterized by particular patterns of language with underlying meaning of purchasing a promoted product (Toolan, 1988). Thus advertisement is a good example of the creative use of persuasive strategies which can be illustrated through language. This study aims to explore amulet advertisements as examples of persuasive discourse widely found in Thailand. In the Thai context, the advertising of amulets and Buddha images seem prevalent in a wide range of printed media - leaflets, newspapers, magazines, and books. Data for this paper are drawn from three amulet advertisements (collected from March 2005 to March 2007). All of them are taken from Thailand's best selling-printed newspaper - Thairath. The linguistic framework used in this study is Systemic Functional Linguistics, initially developed by Michael A. K. Halliday. Two key aspects of SFL are analysed context and lexicogrammar strata. Based on the Thai context, three contextual values - field, tenor, and mode are discussed. In terms of lexicogrammatical analysis, the study will focus on an exploration of three metafunctions - textual, interpersonal, and experiential.
\end{abstract}

\section{Introduction}

Buddhism is the main religion of Thailand. More than 90 percent of Thai people are Buddhists. The Buddhist elements can be seen through different forms - Buddhist monks, Buddhist items, Buddhist architecture, and religious services. Nowadays the rigour of Buddhist practice has changed. An orthodox understanding of the Buddhist teaching, Dharma, 
has become corrupted by a superstition-stained belief in the power of Buddhist trinkets, images and amulets in the belief that they will bring luck and protection to possessors.

In the Thai context, amulet advertisements are prevalent in a wide range of printed media - leaflets, newspapers, magazines, and books. A number of studies have investigated the role of mass media in the commercially Buddhist materialism (Wongsasuluk, 1993; Pavavimol, 1994). However, a linguistic analysis of amulet advertisements has yet to be undertaken, especially how the language of persuasion is grammatically characterized in amulet advertisements.

This research aims to extend Thai discourse studies based on narratives and news reports towards persuasive discourse. It is concerned with an exploration of advertising discourse in general and amulet advertisements in particular. The research was drawn from three amulet advertisements published in the best selling Thai newspaper - Thairath. It illustrates how persuasive discourse is lexicogrammatically explored by investigating three metafunctions - system of THEME, system of MOOD, and system of TRANSITIVITY.

\section{Theoretical remarks}

This section deals with the theoretical framework applied to this research. A brief introduction of Systemic Functional Linguistics is provided in relation to its foundation, its perspective on language, key figures and its discourse contributions. It is followed by two key concepts of SFL: lexicogrammar stratum and metafunction dimension.

\subsection{An introduction to Systemic Functional Linguistics}

Systemic Functional Linguistics (henceforth SFL) was developed by Michael A. K. Halliday in the mid nineteen century. It was further developed by key figures in this field including Ruquiya Hasan, James R. Martin, Christian M. I. M. Matthiessen, and David Butt. Systemic functional theory has been developed to be a general linguistic resource applicable to a wide range of question about language (Caffarel, Martin and Matthiessen, 2004: 6). This range of concerns includes language development, educational linguistics, computational linguistics, clinical linguistics, modelling of language, multilingual studies, stylistics, and the study of verbal art; and multimodal studies. SFL views language as a complex adaptive semiotic system for making meaning. This adaptive system is "elastic", constantly reshaping and extending itself(Halliday, 2000: 230).

In systemic functional theory, language is organized as a multidimensional semiotic space according to: (i) the hierarchy of stratification (semantics, lexicogrammar and phonology or graphology); (ii) the metafunctional spectrum of meaning (ideational: experiential, logical, interpersonal and textual); and (iii) the cline of instantiation (the cline between potential and instance). Within each stratum, language is organized locally according to rank (clause, group/phrase, word and morpheme), axis (paradigmatic organization represented by system networks and syntagmatic organization represented by function structures) and delicacy (less delicate to more delicate). 
This study is concerned with the clause-rank system at the stratum of lexicogrammar, across the metafunctional spectrums. A brief description of lexicogrammar stratum and metafunction dimension is given in the following sections.

\subsection{Lexicogrammar stratum}

This study is concerned with an analysis of amulet advertisements at the stratum of lexicogrammar. Lexicogrammar is the system of wording. It serves as a resource realizing meaning as wording (i.e., for expressing meaning by means of grammatical and lexical items, and by means of grammatical structures). The Lexicogrammar is the abstract level of coding that is the heart of language (Halliday, 1985: 8); it is located as an abstract interlevel between phonology and semantics as shown in Figure 1:

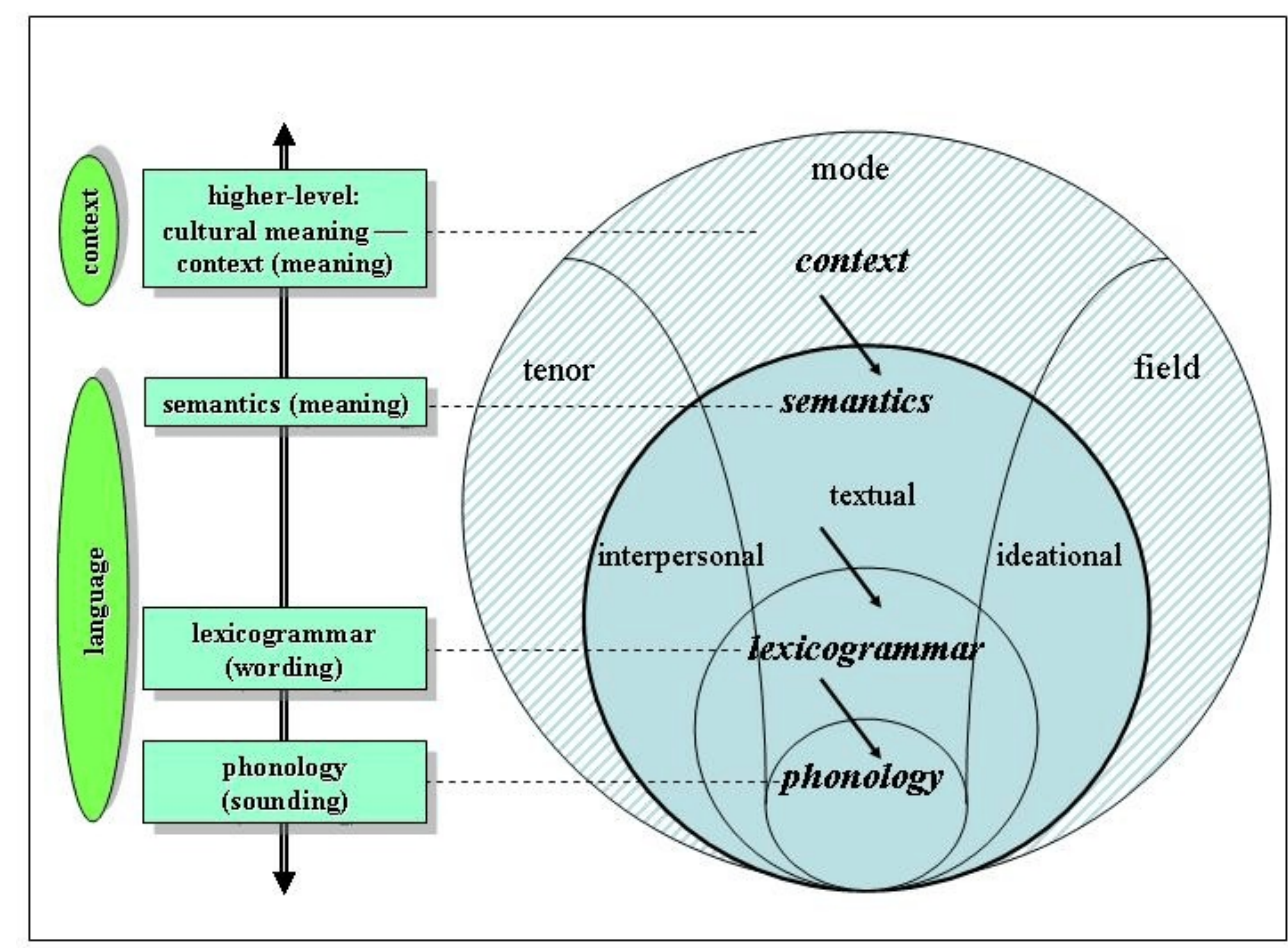

Figure 1. Location of lexicogrammar in the division of stratification dimension.

\subsection{Metafunctional perspective}

This study analyses three amulet advertisements through three main metafunctional analyses of meaning. From the perspective of metafunction, language is interpreted as a meaning potential diversified functionally into three simultaneous modes of meaning: ideational, interpersonal and textual. 


\subsubsection{Ideational metafunction}

The ideational metafunction is concerned with "ideation", and with construing our experience of the world around us and inside us. It provides the potential for creating, maintaining, and revising knowledge in the form of meaning (the semantic system); for classifying, reasoning about, and modelling our experience, both in "common sense" - folk-ways, and in "uncommon sense" - scientific ways (Matthiessen, 1995; Halliday and Matthiessen, 1999). The ideational metafunction can be divided into two subtypes embodying different modes of construing experience - experiential and logical. The experiential metafunction construes experience in terms of configurations, such as the configuration of a process, participants involved in it and attendant circumstances, and its grammatical system is TRANSITIVITY. The logical metafunction construes experience as chains, developed out of highly generalized relations such as elaboration, exemplification and modification, and its grammatical systems include TAXIS and LOGICO-SEMANTIC TYPE. The ideational metafunction is relatively used to analyse both monologic and dialogic passages.

\subsubsection{Interpersonal metafunction}

The interpersonal metafunction is concerned with the interaction between speaker and listener. It involves the grammatical resources for enacting social roles in general, and speech roles in particular, in dialogic interaction: for example, resources for establishing, changing, and maintaining interpersonal relations. The major grammatical system of the interpersonal metafunction is the system of MOOD. The interpersonal metafunction is a useful framework to analyse dialogic passages (cf. Eggins and Slade, 1997).

\subsubsection{Textual metafunction}

The textual metafunction involves the creation of text. It is a resource for presenting interpersonal and ideational meanings as information organized into text unfolding in context. It enables the speaker or writer to construct "texts", or connected passages of discourse, that are situationally relevant. The major grammatical systems of the textual metafunction include THEME, INFORMATION, and REFERENCE. The textual metafunction is used to analyse both monologic and dialogic passages.

\section{The language of advertisement}

Colley (cited in Bosworth, 2005: 239) states that "advertisement is mass, paid communication, the ultimate purpose of which is to impart information, develop attitude and induce action beneficial to the advertiser (generally the sale of a product or service)". Belch and Belch (1998: 711) provide a precise definition of advertisement as "any paid form of nonpersonal communication about an organization, product, service, or idea by an identified sponsor". In the research context, advertisement is an interesting research topic. 
Advertisement is studied in many disciplines, namely mass communication, fields related to business administration (i.e., economics, marketing), and linguistics. In terms of linguistics exploration, the language of advertising was thoroughly studied by Leech (1966). Leech provides preliminary exploration of standard advertising English. His study of advertising language is based on Halliday's contribution (Halliday, 1961). Based on SFL, Leech's study covers two main dimensions: STRATIFICATION (i.e., lexicogrammar, semantics, and context) and RANK (i.e., words (including compound words), groups / phrases (including nominal groups and verbal groups), and clauses).

Advertising is also explored in terms of its strategic goals. Vestergaard and Schrøder (1985) elaborate on a prototypical description of strategic goals of advertising copy proposed by Lund (1947). Five strategic goals that should be achieved by advertisers are attracting prospective customer's ATTENTION, arousing INTEREST, stimulating DESIRE, creating CONVICTION, and getting a positive ACTION (as cited in Vestergaard and Schrøder, 1985:49).

Advertising language was later studied by other scholars. Toolan (1988) proposes structural components of advertisements. He also provides a guideline of standard features of English advertisements. Dyer (1988) examines advertising as a form of communication in contemporary societies and discusses it in its cultural and economic context. Some aspects of advertising language are also examined. Cook (1992) explores advertisements as a discourse type. That is, advertising is viewed as a prominent discourse type in all contemporary societies. This author provides a comprehensive introduction to advertising discourse by investigating the language of complementary advertisements. Fourteen prototypical features of advertisements are also provided (Cook, 1992: 214). In addition, the study of advertising language was studied in terms of information prominence by Fries (1993). In his study, advertisements are investigated in terms of Theme-Rheme structure. A new term is coined, "N-Rheme" (for New Rheme), referring to the last constituent of clause simplexes or clause complexes. In this study, N-Rhematic information and Thematic information are investigated and compared to see where information which is directly relevant to the persuasive goals of the advertisements (e.g., company or product name, product features, product functions, product evaluations) is placed in the clause structure. The study reveals that those persuasive functions of advertising typically are placed at the N-Rheme position and given focal attention.

The previous studies explore advertising language as it is embedded in context of situation. That is, one cannot study advertisement without a general picture of the relation between language and situation (Leech, 1966: 4).

\section{Location of advertisement in Ure's text typology (1989) and text selection}

Ure (1989) proposes a significant framework for classifying texts, widely known as text typology (see Table 1). The text typology is based on four dimensions: specialization (specialized and non-specialized), medium (spoken and written), social purpose (expounding, reporting, recreating, sharing, recommending, enabling, exploring, and doing), and experiential domain (reflection and action). 


\begin{tabular}{|c|c|c|c|c|c|c|c|}
\hline & \multicolumn{2}{|l|}{ written } & \multicolumn{2}{|l|}{ spoken } & & \\
\hline & & dialogue & monologue & & dialogue & & \\
\hline \multirow[t]{2}{*}{ specialized } & 1 & Letter & $\begin{array}{l}\text { Reference } \\
\text { book }\end{array}$ & Lecture & Debate & \multirow[t]{2}{*}{ expounding } & \multirow[t]{10}{*}{ reflection } \\
\hline & & Menu & Text book & & & & \\
\hline \multirow[t]{16}{*}{$\begin{array}{l}\text { non- } \\
\text { specialized }\end{array}$} & 2 & Questionnaire & History & $\begin{array}{l}\text { Statement in } \\
\text { evidence }\end{array}$ & $\begin{array}{l}\text { Cross } \\
\text { examination }\end{array}$ & \multirow[t]{3}{*}{ reporting } & \\
\hline & & & Biography & & & & \\
\hline & & & News report & & & & \\
\hline & 3 & Comic strip & Memoirs & $\begin{array}{l}\text { Radio } \\
\text { commentary }\end{array}$ & Drama & \multirow[t]{4}{*}{ recreating } & \\
\hline & & & Novels & & & & \\
\hline & & & & & Folk play & & \\
\hline & & & Stories & & $\begin{array}{l}\text { Collaborative } \\
\text { narrative }\end{array}$ & & \\
\hline & 4 & $\begin{array}{l}\begin{array}{l}\text { Letter, } \\
\text { personal }\end{array} \\
\end{array}$ & Diary & Reminiscence & Conversation & sharing & \\
\hline & 5 & $\begin{array}{l}\text { Letter, } \\
\text { business }\end{array}$ & - & - & Co-operation & doing & \multirow[t]{8}{*}{ action } \\
\hline & 6 & $\begin{array}{l}\text { Letter, } \\
\text { agony aunt }\end{array}$ & Advertisements & Prayers & Consultation & \multirow[t]{4}{*}{ recommending } & \\
\hline & & & Blurb & & & & \\
\hline & & & Advice & & $\begin{array}{l}\text { Business } \\
\text { messages }\end{array}$ & & \\
\hline & & & Warnings & & & & \\
\hline & 7 & $\begin{array}{l}\text { Open letter: } \\
\text { exhortation }\end{array}$ & $\begin{array}{l}\text { Act of } \\
\text { parliament }\end{array}$ & Sermon & Demonstration & \multirow[t]{3}{*}{ enabling } & \\
\hline & & & Regulations & & & & \\
\hline & & & Knowledge & & & & \\
\hline \multirow[t]{2}{*}{ specialized } & 8 & $\begin{array}{l}\text { Letter to the } \\
\text { editor }\end{array}$ & Critical studies & $\begin{array}{l}\text { Speech } \\
\text { (TV talks) }\end{array}$ & Discussion & \multirow[t]{2}{*}{ exploring } & \multirow[t]{2}{*}{ reflection } \\
\hline & & & Investigations & & & & \\
\hline
\end{tabular}

Table 1. Ure's text typology (1989).

Based on Ure's text typology, advertisements are located in non-specialized, monologic written medium, recommending social process, and action domain.

This study was a preliminary research. It aims to explore a grammatical perspective on discourse and to build up a corpus-based analysis of advertisement text type (cf. Ure, 1989). In terms of text selection, three amulet advertisements are selected and analysed. They were taken from the best selling Thai newspaper-Thairath. The three selected texts were collected from March 2005 to March 2007. There were 82 relative frequencies of printed copies of these three amulet advertisements. There are 115 clause complexes and 468 clause simplexes (see Table 2). 


\begin{tabular}{|c|c|c|c|c|c|}
\hline Text & Title and its Capture & $\begin{array}{l}\text { frequencies } \\
\text { of print }\end{array}$ & $\begin{array}{l}\text { clause } \\
\text { complexes }\end{array}$ & $\begin{array}{l}\text { clause } \\
\text { simplexes }\end{array}$ & $\begin{array}{l}\text { total of } \\
\text { words }\end{array}$ \\
\hline 1 & $\begin{array}{l}\text { Pho Pu Chu Chok Phoem Phun Sap } \\
\text { It sends power as wished. It brings } \\
\text { good trade, finance, and great fortune. }\end{array}$ & 40 & 33 & 125 & 1,034 \\
\hline 2 & $\begin{array}{l}\text { Nok Khum Ma Rum Riak Sap } \\
\text { Recently a believer of Luang Pho } \\
\text { Khun won a jackpot of } 38 \text { million } \\
\text { baht. }\end{array}$ & 24 & 54 & 253 & 1,866 \\
\hline 3 & $\begin{array}{l}\text { Cia Buay } \\
\text { It brings fortune. It provides for good } \\
\text { trade and business. }\end{array}$ & 18 & 28 & 90 & 818 \\
\hline & Total & 82 & 115 & 468 & 3,718 \\
\hline
\end{tabular}

Table 2. Text selection and number of clauses analysed.

Before the lexicogrammatical analysis is undertaken, the context of advertisement discourse is discussed. The discussion covers social purpose of advertisement (i.e., recommending goods-and-services) in relation to contextual values (i.e., field, tenor and mode). It is followed by a discussion of text structure, where the three contextual values can be realized structurally by different stages.

\section{Context of advertisement discourse}

This section is concerned with context of advertisement discourse in general and amulet advertisements in particular. Based on SFL, context can be interpreted as a semiotic system (Halliday, 1978), more specifically as a "connotative" semiotic (Martin, 1992: Chapter 7). A connotative semiotic is one that has another semiotic system as its expression plane; in the case of context, this is language and other denotative semiotic systems (semiotic systems with their own expression planes): context is realized by language, gestures, gaze and other aspects of "body language", as in oral story-telling. Context thus serves to give value to, and to integrate, these different semiotic systems.

\subsection{Context of recommending goods-and-services: advertisement: amulet advertisements}

Language is viewed as one kind of a higher-order semiotic system - a complex and adaptive system for making meaning (Halliday, ibid: 7, Matthiessen, 2001). This means that language is explored "ecologically", and it is always investigated in relation to, instead of being insulated from, its environment. In other words, language is investigated through naturally occurring texts functioning in its context.

The realization of context in language is based on the metafunctional spectrum: field is realized by the ideational metafunction, tenor by the interpersonal one and mode by the textual one (Halliday, 1978; Halliday and Hasan, 1985; Martin, 1992). Based on Halliday (1977:200$201 ; 1985: 12 ; 1978: 142-143)$, the three contextual values are described as follows: 
Field (the social action): is "that what is 'going on', and has recognizable meaning in the social system; typically a complex of acts in some ordered configuration, and in which the text is playing some part, and including 'subject matter' as one special aspect".

Tenor (the role structure): is concerned with "the cluster of socially meaningful participant relationships, both permanent attributes of the participants and role relationships that are specific to the situation".

Mode (the symbolic organization): relates to "the particular status that is assigned to the text within the situation; its function in relation to the social action and the role structure, including the channel or medium, and the rhetorical mode".

In order to give a contextual situation of the advertisements (recommending goods-andservices), I also characterized the contextual values of amulet advertisements in which it occur in terms of field, tenor and mode. Table 3 summarizes the three contextual values of the amulet advertisement discourse.

\begin{tabular}{|l|l|l|}
\hline Field & socialprocesses & $\begin{array}{l}\text { commercial recommendation; recommending goods-and-services to } \\
\text { a prospective public through giving information strategy mass media; } \\
\text { newspaper (printed forms) }\end{array}$ \\
\cline { 2 - 3 } & social action & persuade engaged customer to purchase goods-and-services \\
\cline { 2 - 4 } & domain & $\begin{array}{l}\text { nature of information being given: } \\
\text { information given with attitudinal favour }\end{array}$ \\
\hline Tenor & institutional role & copy writer - prospective customers/engaged customers \\
\cline { 2 - 4 } & hierarchy & $\begin{array}{l}\text { unequal: copy writer as an expert - engaged customers as a novice in } \\
\text { this particular of information }\end{array}$ \\
\cline { 2 - 4 } & interactant & $\begin{array}{l}\text { Expert: copy writer } \\
\text { Audience: interested public, especially amulet buyers, who are } \\
\text { seeking for good luck and fortune, plus some groups of special } \\
\text { concerns (whose actions many be affected by the information, e.g., } \\
\text { amulet producers) }\end{array}$ \\
\hline \multirow{5}{*}{ Mode } & no specific relationship between copy writers and engaged customers \\
\cline { 2 - 3 } & distance & information giver - information receiver \\
\cline { 2 - 3 } & turn-taking & written: print: prose format with photographic presentation \\
\cline { 2 - 4 } & rhetoricalmode & $\begin{array}{l}\text { persuasive mode, the symbolic organization of the text involving the } \\
\text { pragmatic purpose oriented to the field of public interest; it is } \\
\text { accompanied by other visual modes: photos of successful } \\
\text { individuals, amulets sold }\end{array}$ \\
\hline
\end{tabular}

Table 3. The context of advertisement discourse.

\subsection{Context realization: text structure}

As mentioned above, at the contextual stratum, advertisements can be viewed in terms of the variables of field, tenor and mode. These contextual values can be realized structurally by different stages unfolding through time. Leech (1966: 59) proposes a press advertisement structure which is composed of Headline, Body copy, Signature line, and Standing details. This advertisement structure is further elaborated on and discussed by Toolan (1988: 55). He 
proposes five typical components of advertisement. They are Headline, Body copy, Signature line, Slogan, and Standing details. This typical structure is presented together with product's illustration.

In SFL, the structural stages mentioned above are known as "Generic Structure Potential" (henceforth GSP). The interest in generic (or schematic) structure of texts has been greatly influenced by Hasan (Halliday and Hasan, 1985; Hasan, 1978, 1984b, 1984c, and 1996) and Martin (1985, 1992). Fahey (2005) proposes a Generic Structure Potential of magazine advertisements, illustrated in Figure 2.

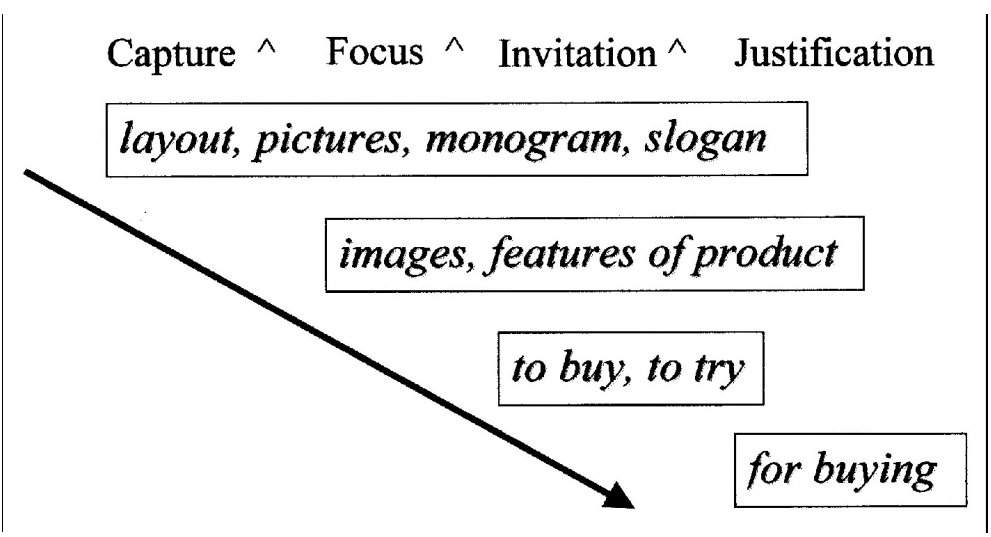

Figure 2. Fahey's Generic Structural Potential of magazine advertisements.

This research is based on Hasan's generic structure approach. The GSP of the three texts is presented below:

GSP of Text 1: Pho Pu Chu Chok Phoem Phun Sap

Capture $\wedge^{\wedge}$ Product attribute ${ }^{\wedge}$ Historical brief ${ }^{\wedge}$ Justification of production ${ }^{\wedge}$ Experience ${ }^{\wedge}$ Purchase information

GSP of Text 2: Nok Khum Ma Rum Riak Sap

Capture ${ }^{\wedge}$ Orientation ${ }^{\wedge}$ Product production $I^{\wedge}$ Experience ${ }^{\wedge}$ Product production $\mathrm{II}^{\wedge}$ Purchase information

GSP of Text 3: Cia Buay

Capture ${ }^{\wedge}$ Product attribute ${ }^{\wedge}$ Bibliography of amulet producer ${ }^{\wedge}$ Experience ${ }^{\wedge}$ Purchase information

It can be noted that the Capture, the Purchase Information and Experience stages are compulsory phases in producing amulet advertisements. The Capture is the crucial part which is intentionally placed right at the beginning of the advertisement structure in order to attract the prospective customer's attention, whereas the Purchase Information phase is the important part and placed at the end of the advertisements. It aims to leave the final message with the 
customer in order for him or her to take a positive action (i.e., buying the advertised product).

The Experience stage is the crucial stage in all advertisements. It makes up the highest proportion of clauses. Successful experiences of amulet believers, who believe in and worship the advertised amulets, are detailed in the advertisements. The advertisement consumer can see and later contextualise changes towards a better life for the amulet believer, before and after worship or practice using the amulets. This message is powerful. It arouses and stimulates the prospective customer's interest and desire to become one of amulet's successful believers. The Product attribute and the Product production stages are optional but preferable. They are carefully crafted in order to achieve the persuasive goals of the advertisements (i.e., elaborating product features, qualities and functions, influencing the customer's decision making). Other stages (e.g., Orientation, Historical brief, Justification of production, Bibliography) are optional stages.

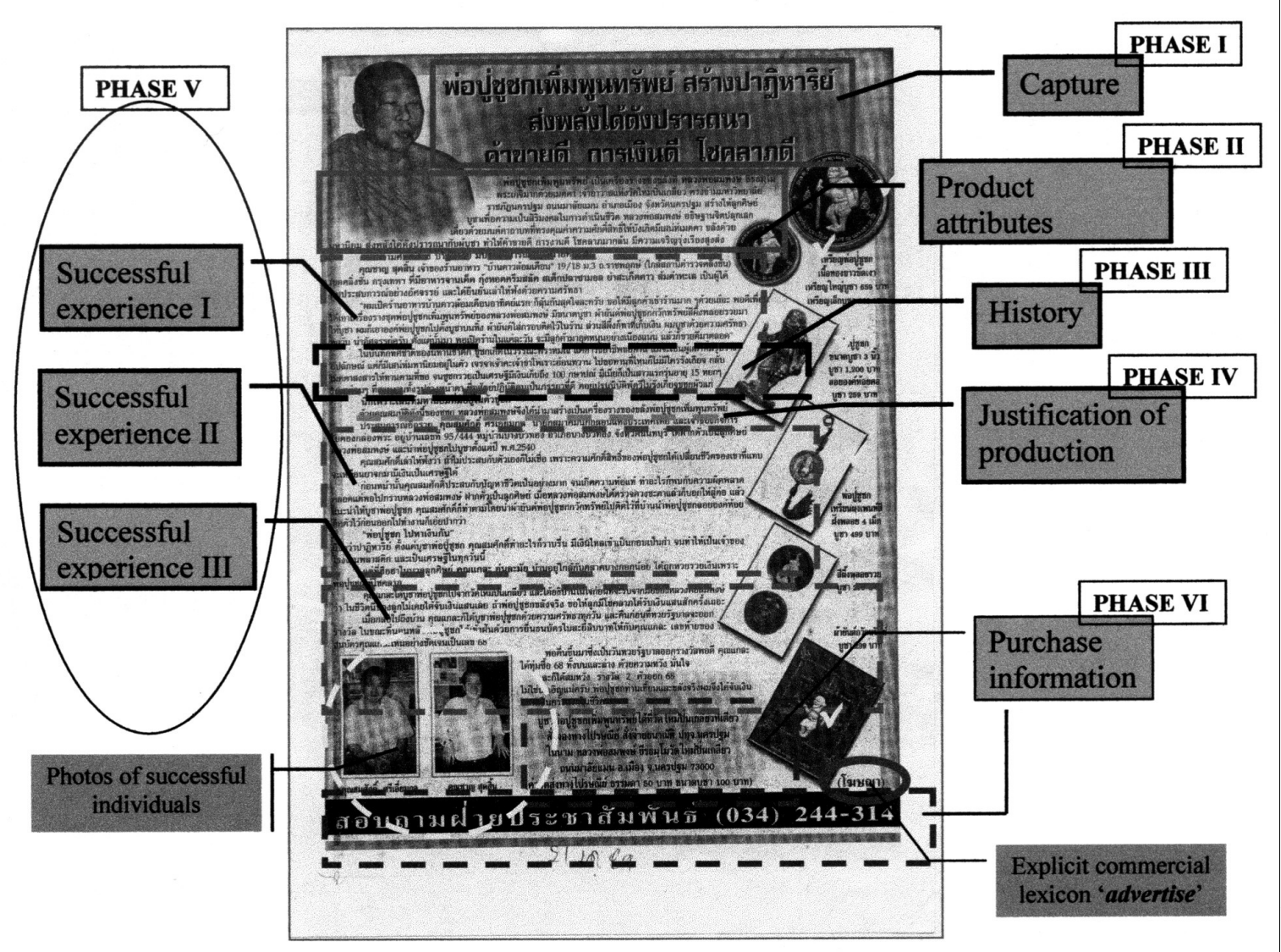

Figure 3. Representation of the six stages in Text 1.

The GSP of the three Thai amulet advertisements can be generalized into ten generic stages. In terms of GSP representation, Hasan's symbols and notions for describing nursery tales are used, supplemented by a few extra symbols to customize to Thai advertisements as shown below: 
Capture $\wedge($ Orientation $) \wedge(\text { Bibliography })^{\wedge}\left[\left(\right.\right.$ Product attribute $\left.^{\mathrm{N}}\right) \cdot\left(\right.$ Product production $\left.^{\mathrm{R}}\right)$ $\wedge^{\wedge}\left[(\text { History })^{\wedge}(\text { Justification })^{\wedge}\right]\left[\left(\text { Pre-Experience }{ }^{\mathrm{N}}\right)^{\wedge}\right.$ Experience $\left.^{\mathrm{N} \wedge}\right]$ Purchase information

() round brackets: enclose optional elements such as Orientation, Bibliography.

No round brackets: indicate obligatory elements

[] square bracket: enclose the boundaries of a limitation of sequence. Indicated by enclosing the relevant elements, because mobile elements are mobile within certain limits

$\wedge$ carat sign: indicate relative sequence

/ slant sign: indicate a complementary distribution of the two elements occurring preceding and following the slant sign

- dot sign: indicate that the order of the elements on the two sides of the dot is reversible.

Superscript $^{\mathrm{N}}$ : indicate the possibility of several occurrences for that element

Superscript ${ }^{\mathrm{R}}$ : indicate the possibility of iteration for that element

Symbols and notions of Generic Structure Potential (adapted from Hasan, 1984a, 1984b)

Due to limitation of space, this paper is concerned with a detailed GSP representation of Text 1 (See Figure 3). Each generic stage of Text 1 is shown in Table 4.

Text 1: Pho Pu Chu Chok Phoem Phum Sap

\begin{tabular}{|l|l|l|l|l|l|l|}
\hline \multicolumn{1}{|c|}{ Phase } & \multicolumn{1}{|c|}{ Stage I } & \multicolumn{1}{|c|}{ Stage II } & \multicolumn{1}{c|}{ Stage III } & \multicolumn{1}{|c|}{ Stage IV } & \multicolumn{1}{c|}{ Stage V } & \multicolumn{1}{c|}{ Stage VI } \\
\cline { 2 - 7 } & Capture & $\begin{array}{l}\text { Product } \\
\text { attribute } \\
\text { (s) }\end{array}$ & $\begin{array}{l}\text { Historical } \\
\text { brief }\end{array}$ & $\begin{array}{l}\text { Justification } \\
\text { of production }\end{array}$ & $\begin{array}{l}\text { Successful } \\
\text { experience }\end{array}$ & $\begin{array}{l}\text { Purchase } \\
\text { information }\end{array}$ \\
\hline $\begin{array}{l}\text { Range of } \\
\text { clauses }\end{array}$ & $\begin{array}{l}\text { Clauses: } \\
1-4\end{array}$ & Clauses: $5-6$ & $\begin{array}{l}\text { Clauses: } 7- \\
12\end{array}$ & Clauses: 13 & $\begin{array}{l}\text { Clauses: } 14- \\
28\end{array}$ & $\begin{array}{l}\text { Clauses: 29- } \\
33\end{array}$ \\
\hline $\begin{array}{l}\text { Number } \\
\text { of clause } \\
\text { simplexes }\end{array}$ & 5 clauses & 12 clauses & 21 clauses & 1 clause & 78 clauses & 7 clauses \\
{$[4.03 \%]$} & {$[16.93 \%]$} & $0.68 \%]$ & {$[62.90 \%]$} & {$[5.65 \%]$} \\
\hline
\end{tabular}

Table 4. Generic Structure Potential of Pho Pu Chu Chok Phoem Phum Sap.

Table 4 shows there are six different stages make up Text 1 . Based on text structure, each stage is unfolded through time and it is organized in terms of linear structure. Stage V is highly elaborated, as there are a number of clauses constructing this stage. Figure 3 shows the six stages of GSP as they present in amulet representation.

The following section deals with lexicogrammatical analysis of three metafunctions. It begins with textual metafunction - system of THEME. This is followed by interpersonal metafunction - system of MOOD. The metafunctional analysis ends with experiential metafunction - system of TRANSITIVITY.

\section{Textual analysis: the textual clause grammar: the system of THEME}

Halliday and Matthiessen (2004: 64) describe that Theme is the element which serves as the point of departure of the message; it is that which locates and orients the clause within its 
context. The reminder of the message, the part in which the Theme is developed, is called in Prague school terminology the Rheme.

In the message structure, a clause consists of a Theme accompanied by a Rheme; and the structure is expressed by the order - Theme + Rheme structure. Matthiessen (1995: 532) outlines the characteristics of Theme and Rheme in terms of their positions organized in unfolding texts (see also Martin, Matthiessen, and Painter, 1997: 22.). Theme (the first element) is placed at the initial position of the clause, whereas Rheme (the rest of the clause) is found at the position following the initial position. The Theme is sometimes referred to as being 'given' information and the Rheme as 'new' information (for further discussion on Given and New information see Halliday and Matthiessen, 2004).

Theme-Rheme structure provides the speaker/writer with strategies for guiding the listener/reader in interpreting of the text in terms of how text is organized, what is the text's method of development. Therefore analysing the thematic structure of a text clause by clause provides an insight view into text organization.

Besides the significance of Theme-Rheme structure, textual metafunction also includes a notion of Theme choices. Theme choices or Theme selections include contributions from all three metafunctions - textual, interpersonal, and topical (experiential) Themes. In this study, all the three metafunctions make up the Theme structure in the three amulet advertisements. Table 5 presents a sequential order and possible Theme choice in the three amulet texts.

\begin{tabular}{|c|c|c|c|c|}
\hline \multicolumn{4}{|l|}{ Theme } & \multirow[t]{2}{*}{ Rheme } \\
\hline $\begin{array}{l}\text { textual } \\
\text { [optional] }\end{array}$ & $\begin{array}{l}\text { interpersonal } \\
\text { [optional] }\end{array}$ & $\begin{array}{l}\text { topical } \\
\text { (experiential) } \\
\text { [obligatory] }\end{array}$ & textual [optional] & \\
\hline $\begin{array}{l}\text { conjunction: }> \\
\text { - adverbial group } \\
\text { relative element: } \\
\text { - relative nominal } \\
\text { group } \\
\text { (clause) binder: } \searrow \\
\text { - binding nominal } \\
\text { group }\end{array}$ & $\begin{array}{l}\text { vocative: } \searrow \\
\text { - nominal group: } \\
\text { kinship term }\end{array}$ & $\begin{array}{l}\text { unmarked: } y \\
\text { - nominal group } \\
\text { - verbal group } \\
\text { marked: } \searrow \\
\text { - prepositional } \\
\text { phrase }\end{array}$ & $\begin{array}{l}\text { conjunction: } \boldsymbol{y} \\
\text { - adverbial group: } \\
\text { (conjunction group } \\
\text { including conjunctions } \\
k \rightarrow: 3 \text { 'then', } c \rightarrow N 1 \\
\text { 'then') }\end{array}$ & \\
\hline
\end{tabular}

Table 5. The sequential order and possible Theme in the three amulet advertisements.

\subsection{Textual Theme}

The textual Theme is almost always the first part of the Theme, coming before any interpersonal Theme. It gives thematic prominence to textual elements with a linking function. Theme resources include (i) conjunction; (ii) relative element; and (iii) clause binder).

Conjunction: A conjunction is a word or group that either links or binds the clause to which it connects message to the previous clause. Conjunctions thus indicate a conjunctive relationship with previous discourse. In a clausal structure, the conjunctive relationship maybe (i) a single conjunction, for example, ja: 2 thi:3 'as', to:2, to: $2 l \propto: w 4$ 'but', loe:4 'and', ta 
ฤ3toe:2 'since' or (ii) a combination of two conjunctions, for example, ta $\eta 3$ toe:2nan 4ma:1 ...ph०::1_ 'since then', to: 2 ... pho:1 'but when'.

(1) Text 2: Conjunction

... (Ø man1) na:2ca2 ra:p3r:n3 toe:loe:w4 (Ø man1) maj3 da:j3pen1

... (it) should be smooth but (it) NEG. be

ja:N2thi:3 (Ø phom3) khit4 waj4 lə:j1

as (I) think keep pass

'(It) should be smooth, but (it) was not (as smooth), as (I) thought.'

Relative element: Relative elements link the clause in which they occur to another clause. They are thematic in nature, and therefore they tend to occur in the initial position. There are two relative elements found in the three amulet advertisements - thi:3 'that', 'who', $s N 3$ 'which'. Relative element thi:3 'that' is the most common. Textually, the relative elements serve as both structural textual Theme and topical (experiential) Theme.

(2) Text 1:Relative element

mial pen1 sa:w5 ro:k3run3 ?a:1ju4 sip2ha:3 jok2 jok2 sip2hok2 jə:n2 jo:n2

wife be female young age 15 little 16 little

[[thi:3 suaj5ja:m1 than4 ru:p3ra:n3 na:3ta:1]]

who be beautiful both body face

'The wife then was a young female aged 15-16 years old who was beautiful both inside and outside.'

Clause binder: A clause binder (wa:3 'that') is one of the structural textual Themes linking the following clause with the preceding clause in clause complexes. In transitivity terms, clause binders tend to occur in mental and verbal processes (e.g., khit4wa:3 'think that', sa:p3wa:3 'know that'; phu:t3wa:3 'say that', law3wa:3 'tell that').

(3) Text 2: Clause binder

... (Ø phuak2rawl) sa:p3 wa:3 caw3kho:n5 ra:n4 toe:n2mo:1 kh:1

... (we) know that owner stall watermelon be

khun1 wanlni4da:1 jo:t3phak2we:n3

Ms. Wanida Yodphakwaen

'(We) know that the own er of the watermelon stall is Ms. Wanida Yodphakwaen.' 
6.2. Interpersonal Theme

An interpersonal Theme foregrounds the speaker's judgment or comments. It might include one or more of the following components: Vocative; Wh-element; and Modal Adjunct.

Vocative: A Vocative is used to directly address the listener, particularly in a dialogic passage. It can be expressed by personal names, kinship terms, occupational terms or pronouns.

(4) Text 1: Vocative

pho:3pu:2 chu:1chok4 paj1 ha:5 nən1 kan1

PhoPhu ChuChok go find money together

'Pho Phu Chu Chok! Let's go and earn some money.'

Wh-element: A Wh-element is an element functioning as thematic element that requests a missing piece of information. Among the most common are: /a $2 \mathrm{raj} 1$ 'what', khraj 'who', thi:3naj5 'where', ma3raj2 'when'.

(5) Text 1: Wh-element

khrajl pen1 caw3kho:n5 ra:n4 tొ:2mo:1

who be owner stall watermelon

'Who is the owner of the watermelon stall?'

Modal Adjunct: A Modal Adjunct represents the speaker's / writer's judgment on, attitude toward, and assessment of, the content of the message. An example is given below.

(6) Text 2: Modal Adjunct

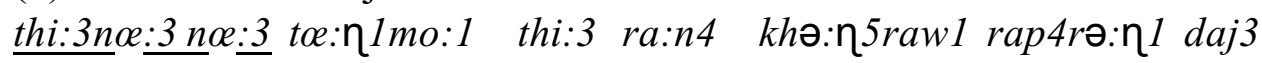

certainly watermelon at stall us guarantee able

'Certainly our watermelons are guaranteed.'

\subsection{Topical (experiential) Theme}

The topical (experiential) Theme includes elements serving a role in the transitivity structure of the clause. It is the starting point from which experiences are unfolded through time. It is the first element in the clause (i.e., the first group or phrase relevant to the experimental function). These thematic elements include: (i) participants (serving as either Subject or Complement; (ii) circumstances; or (iii) processes.

Participant topical Themes can be either Subject Participant (i.e., a Participant serving as a 
Subject) or Complement Participant (i.e., a Participant serving as a Complement). The Complement Participant is likely to be textually recoverable from preceding clauses. Examples are given below.

(7) Text 3: Subject / Participant / Theme taw2 pen1 san5ja:1lak4 kho:n5 khwa:m1jan3j:n1 khoe:n5roe:n1 ?ot2thon1

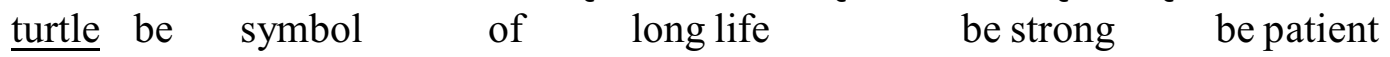

'The turtle was a symbol of long-lasting, strength, and patience.'

(8) Text 1: Complement / Participant / Theme

pha:2jan1 (Ø khaw5) tit2 waj4 na:1 ra:n4

cloth (he) attach to keep in front of (his) shop

'(He) attached a piece of Pho Pu Chu Chok's mystical cloth in front of his shop.'

Circumstantial Themes are typically location in time and space since these relate to the method of advertisement development. In addition, they specify a number of semantic relationships of the Process (the verb) $3 / 4$ extent in time and space (i.e., duration and distance), cause, reason, manner, and accompaniment. Examples of location in time and space are given below.

(9) Text 2: Circumstance: Location of time

to:n1 chaw4 run3khn3 ?i:k2 wan1 mi:1 khon1 la:j5 khon1 ma:1 time early morning more day exist/have person several CL. come

san2 to:n1mo:1 haj3 paj1 son2 kan1 than4 wan1

order watermelon give go delivery together whole day

'Next morning, there were many people ordering her watermelons the whole day'

(10) Text 1: Circumstance: Location of space

naj1 ban1khk4 thot4sa2cha:t3 kho:n3 ni4tha:n1 cha:1dok2 chu:1chok4 kə:t2

in record ten life of tale Jatakas Chu Chok born

najl wanlna4 phra:ml

in caste Brahman

In the record of the ten Buddha Jatakas, Chu Chok (or Jujaka) was born into the Brahman caste.

Process Theme is restricted to imperative clauses. That is, the imperative is the only type of clause in which the Process (the verb) is regularly found as Theme. The process Theme is 
expressed by a verbal group.

(11) Text 1: Process

pajl ha:5 nən1 kanl

go find money together

'Let's go and earn some money'

In addition, the topical (experiential) Theme systems are more complex than the textual and the interpersonal Themes. The topical Theme is concerned with THEME SELECTION - the selection between unmarked and marked Themes. The ratio of unmarked and marked Theme selection in the three amulet advertisements can be illustrated in Figure 4.

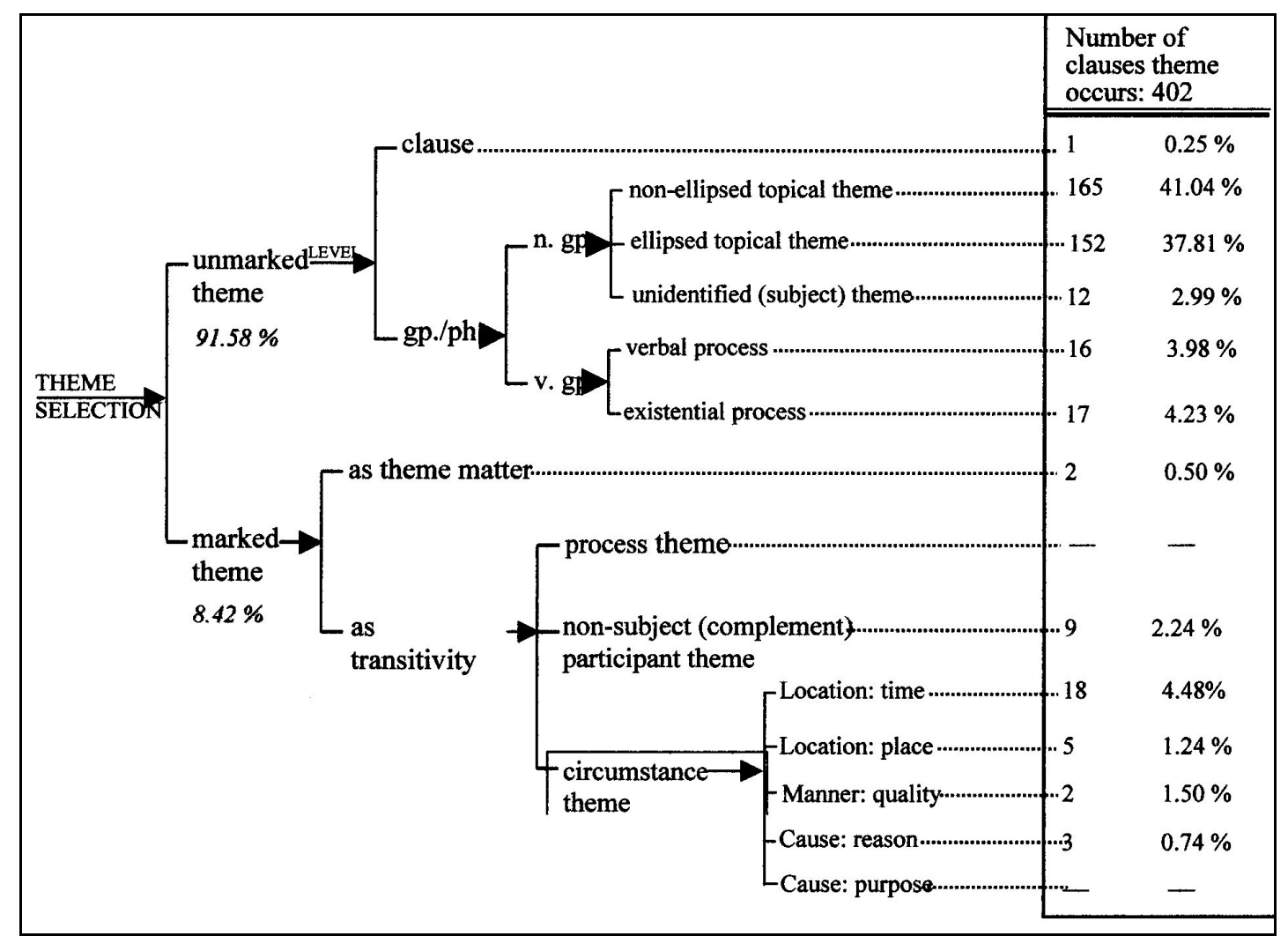

Figure 4. Relative frequencies of Theme types in the three amulet advertisements.

\section{Interpersonal analysis: the interpersonal clause grammar: the system of MOOD}

The interpersonal metafunction is a resource for enacting social roles and relationships between speaker / writer and listener / reader (Matthiessen, 1995: 17). MOOD is one of the main grammatical systems of exchange and negotiation.

Interpersonally, "clause as exchange" is the basic principle of the MOOD grammar: MOOD is the basic resource for exchanging meaning in both dialogue and monologic passages. It is 
the grammar of negotiation (Matthiessen, 2001:3).

There are two fundamental semantic variables in an exchange - the orientation of the exchange and the commodity being exchanged. In turn, speech functional categories are realized by different MOOD sections or choices as shown in Table 6 .

\begin{tabular}{|c|c|c|c|}
\hline & & \multicolumn{2}{|c|}{ commodity } \\
\hline & & information & goods-and-services \\
\hline \multirow{2}{*}{ orientation } & giving & $\begin{array}{l}\text { STATEMENT } \\
\varnothing \text { declarative }\end{array}$ & OFFER \\
\hline & demanding & $\begin{array}{l}\text { QUESTION } \\
\varnothing \text { interrogative }\end{array}$ & $\begin{array}{l}\text { COMMAND } \\
\varnothing \text { imperative }\end{array}$ \\
\hline
\end{tabular}

Table 6. The mood categories as realizations of speech functional categories.

As Table 6 shows, STATEMENT is realized by declarative clauses, QUESTION is realized by interrogative clauses, COMMAND is realized by imperative clauses, and OFFER is realized by various clauses. Figure 5 summarizes relative frequencies of Mood selection in the three amulet advertisements.

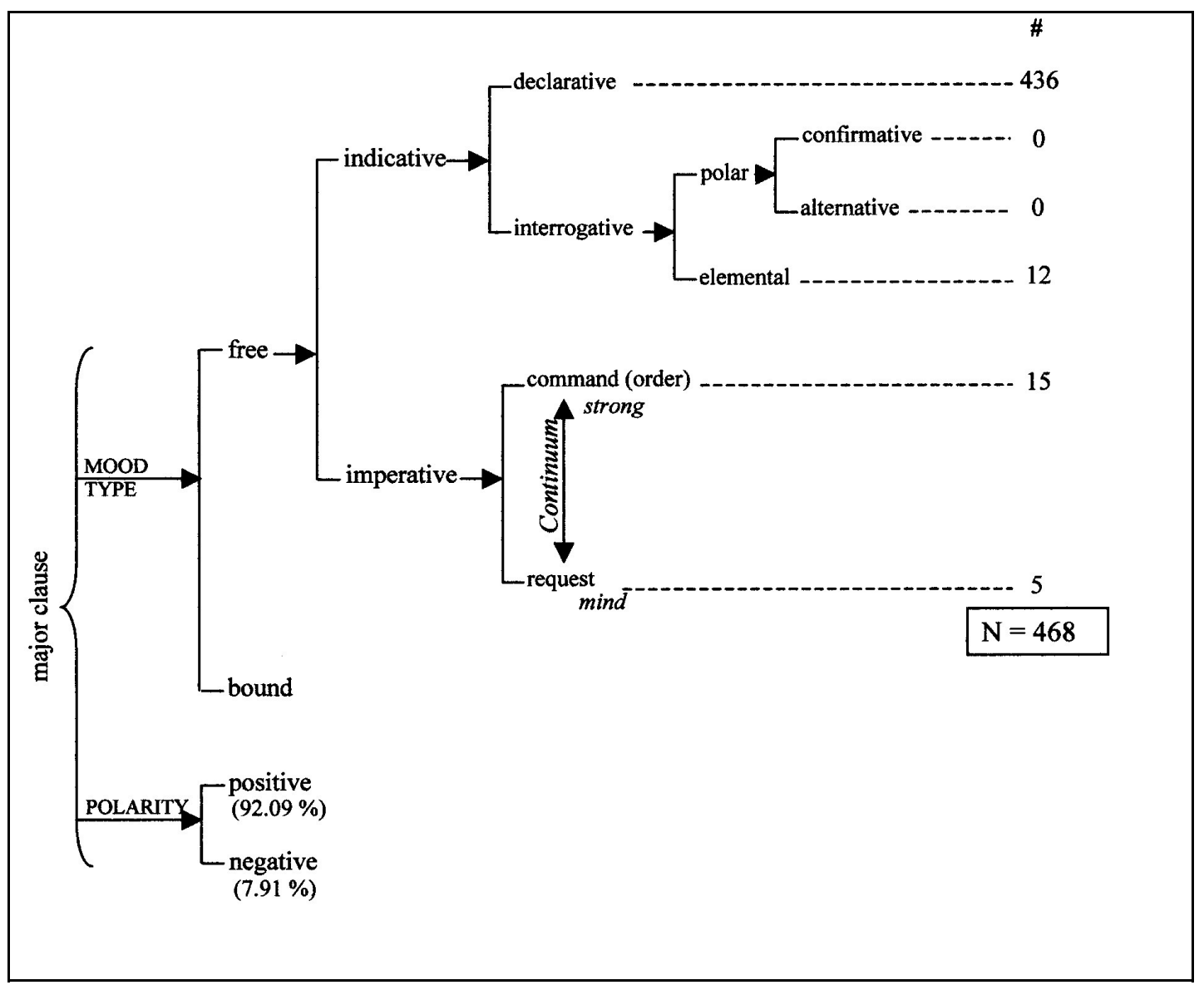

Figure 5. Relative frequencies of Mood selection in the three amulet advertisements. 
Figure 5 shows that declarative clauses are considerably selected in constructing this advertising. The selection of declarative clauses found throughout the text. 20 imperative clauses are found in the three amulet advertisements. $80 \%$ of order (strong command) is found in the "Purchase Information" phase (i.e., buy, book, pay, contact, and phone). $100 \%$ of request (mind command) is found in the "Successful experience" phase (i.e., request for good fortune, luck, and good business).

\section{Experiential analysis: the experiential clause grammar: the system of TRANSITIVITY}

This section is concerned with the system of TRANSITIVITY of the amulet advertisement. Matthiessen (1995: 194) characterizes that the system of TRANSITIVITY is resources for construing (interpreting and representing) human experience of change or on-going-on in the flow of events inside and around us. A quantum of change in the flow of events is construed as a configuration of a process, participant involved, and attendant circumstances.

The TRANSITIVITY system embodies two parts: nuclear TRANSITIVITY (i.e., the transitivity of processes and participants) and circumstantial TRANSITIVITY (i.e., the transitivity of circumstances). Each configuration will be elaborated in turn.

Process, as the process of "meaning", is characterized by its potential for organizing participants into an experiential configuration. In Thai, the process is organized according to verbal group complexity: that is, the process can be expressed by a verbal group simple, or a verbal group complex.

Participants are inherent in process. They physically and mentally take part in the process in a number of specific ways: they may act out the process, they may sense through it, they may say it, they may have some properties related to it, and so on. The participant directly involves with the process. In the clausal structure, there may be one or two additional participants, depending on the nature of the process.

Circumstances are transitivity component, which are typically less associated with the process, and are not inherent in it: that is, they indirectly involve with the process. They specify a number of semantic relationships of the process - temporal or spatial location, extent in time and space (i.e., duration and distance), cause, reason, manner, and accompaniment.

This paper is concerned with an exploration of a configuration of process and participant as these two components constitute the nuclear TRANSITIVITY. In systemic functional terms, the domains of experience are divided into three domains: (i) doing and happening; (ii) sensing and saying; and (iii) being and having. These three experiential domains thus constitute four distinct process types $3 / 4$ material, mental, verbal, and relational. There are two additional, intermediate process types: 'behavioural' processes which are interpreted as a subtype of 'material'; and 'existential' processes which are interpreted as a subtype of 'relational'.

This section illustrates how amulet advertising is represented and resented as the flow of events: how the amulet advertising is presented through the clauses for construing readers' experience (i.e., prospective customers). In terms of process types, there are six process types 
instantiated in the amulet advertisement. The six process types are 'material', 'behavioural', 'mental', 'verbal', 'relational', and 'existential'. The counts are presented in Table 7:

\begin{tabular}{|l|l|c|c|}
\hline process type & subtype & $\#$ & \% \\
\hline \hline \multirow{2}{*}{ material } & happening & 192 & $41.06 \%$ \\
\cline { 2 - 2 } & doing & & \\
\hline behavioural & \multicolumn{2}{|c|}{1} & $0.21 \%$ \\
\hline \multirow{3}{*}{ mental } & perceptive & 56 & $11.97 \%$ \\
\cline { 2 - 2 } & cognitive & & \\
\cline { 2 - 2 } & desiderative & & \\
\cline { 2 - 2 } & emotive & & \\
\hline verbal & \multicolumn{2}{|c|}{50} & $10.68 \%$ \\
\hline relational & attribute & 140 & $29.91 \%$ \\
\cline { 2 - 2 } & identifying & & \\
\hline existential & \multicolumn{2}{|c|}{29} & $6.21 \%$ \\
\hline
\end{tabular}

Instantiation of PROCESS TYPE [ $\mathrm{n}=468$ ]

$[\mathrm{n}=$ number of simple clauses and embedded clauses]

Table 7. Relative selections of process types

Table 7 shows the number of selection of different process types averaged over the three amulet advertisements. This provides a profile of the frequency of instantiation of the system choices which constitute this particular advertising discourse. As the table shows, the most frequent selection is 'material' - transitivity grammar of happening and doing (41.06\%). The second selection is 'relational' - the transitivity grammar of being and having $(29.91 \%)$. The mental process is the third count in terms of process selection $(11.97 \%)$. This is in turn followed by 'verbal' - the transitivity grammar of saying $(10.68 \%)$. The next selection is 'existential' - the transitivity grammar of existing (6.21\%). 'Behavioural' - the transitivity grammar of behaving - is the minor process type in terms of frequency $(0.21 \%)$.

The material process is the most frequently selected of the three amulet advertisements. This is to be expected since the amulet advertisements are typically concerned with the doing of a commodity transaction. The relational process is the second selection. This is quite predictable in this particular text type, as the advertisement copy writer's strategic goal is to grab the potential customer's attention and interest by arousing and stimulating their desire which finally leads to a positive response - purchasing the advertised product. Strategically, arousing interest and desire can be achieved by consistently describing product features, functions, evaluation, and values. The mental process is the third count in terms of process selection. The use of mental processes is necessary since the amulet advertisements provide persuasive information in relation to a successful individual's sensing processes related to the magic power of the advertised amulet (e.g., belief, disbelief, respect, disrespect, knowing, thinking, and realizing). This persuasive message is achieved by continuously referencing to the individual's business and social life experiences before and after becoming an owner and worshipping the advertised amulet. Verbal processes are ranked fourth in terms of frequency. They are expressed by successful amulet believers who narrate their personal miracle experiences and are exploited by reporters who report and interview about the successful 
experiences. Behaviour process is less frequent in this text type.

It is interesting to note that in a larger corpus of amulet advertisements one can anticipate a similar profile of process type selection. The material processes are the most dominant, the second most frequent process types being relational processes. The behaviour processes are the least dominant.

\section{Conclusions}

This paper illustrates a grammatical perspective on discourse by investigating three amulet advertisements. It approaches the amulet advertisements by exploring grammar at work. In terms of contextual stratum, there are ten generic stages constituting the generic structural potential of amulet advertisements. The persuasive goal of advertising is motivated and highlighted by amulet attribution and production. They were endorsed by the shared experiences of successful worshippers. Readers are persuaded by a high expectation of success (wining the lottery, having good luck, and good business).

In the lexicogrammar stratum, the three modes of meaning are explored. Textually, the vast majority of Themes was unmarked topical Themes $(91.58 \%)$. They were selected from among the participants in the advertisement. Therefore, the method of development of this text was the selection of unmarked Themes. It is also organized through the textual Theme (i.e., conjunctions). This amulet was also constructed by marked Themes $(8.42 \%)$. They expressed through Location in time and space, Manner of quality, Cause of reason.

Interpersonally, declarative clauses (giving information) were considerably selected. This was highly motivated, because the amulet advertisement was an informative text in nature. Its focus was on providing information of the product attribute, production, experiences. The sales message was implicitly found throughout the text. The explicit sales message was typically found towards the end of the text. It was grammatically expressed by imperative clauses (demanding for goods-and-services) (i.e., buy, book, pay, contact, and phone).

Experientially, it reveals that the amulet advertisement is construed by different text types. The text involves its various participants in different participant roles associated with different process types. The clear frequency of material processes $(41.06 \%)$ suggests that this amulet advertisement is largely concerned with actions and events. In terms of field contextual value, advertising text is conveyed to a mass audience with an ultimate aim to promote and persuade customer to purchase goods-and-services; in fact, the function of advertising is to present product features, product functions, and evaluations of the products. In this current study, the amulet items are systemically advertised through selection of material processes. In terms of frequency, relational processes are selected in the second rank $(29.91 \%)$. They expressed product attributes, product evaluations and habitude of believers.

Linguistically, this research explores linguistic resources in which amulet advertisements are viewed as examples of persuasive discourses for presenting, enacting, and construing the multi-faceted processes of persuasion. The amulet advertisement, as a commercial consumer advertising, aims to persuade the prospective customer to purchase goods-and-services. Advertising copy writers have used a number of linguistic resources to craft the body copy of 
the advertisements. Structurally, the advertisement is carefully organized in order to achieve strategic goals (i.e., getting a positive response, that is, prospective customer purchases the advertised products.). Objectives of the advertisement structure include capturing prospective customer's attention, arousing and stimulating customer interest, maintaining interest by repeating the product's name, and leaving contact details for further positive reaction (i.e., purchasing the products). However, Thai amulet advertising is different from other types of advertisement in that the experiences of successful amulet believers are artistically crafted aimed at endorsing the amulet's qualities, values, and functions. It is a must stage found in all Thai amulet advertising.

\section{Notes}

1. I would like to express my deepest gratitude to Professor Christian M.I.M. Matthiessen and Dr. Kazuhiro Teruya for their continued supports and encouragement. I wish to express my appreciation and thankfulness to the two anonymous referees for their insightful and valuable comments on the final draft of this paper. I am grateful to Mr Richard Hiam for his editing support.

\section{References}

Belch E. G. and Belch A. M. (1998): Advertising and Promotion: An Integrated Marketing Communications Perspective. Irwin: McGraw-Hill.

Bosworth, Derek L. (2005): Determinates of enterprise Performance. Manchester: Manchester University Press.

Caffarel, Alice, James R. Martin and Christian M.I.M. Matthiessen (2004): "Introduction: systemic functional typology." In A. Caffarel, J. Martin and C. Matthiessen., eds., Language Typology: A Functional Perspective. Amsterdam: John Benjamins, 1-76.

Cook, Guy (1992): The Discourse of Advertising. New York: Routledge.

Dyer, Gillian (1988): Advertising as Communication. London: Routledge.

Eggins, S. and D. Slade (1997): Analysing Casual Conversation. London: Cassell.

Fahey, Rhondda (2005): "Language of advertising." BBA 316's handout. MS. Department of Linguistics, Macquarie University

Fries, Peter H. (1993): "Information flow in written advertising." In James Alatis, ed., Language, communication and social meaning. Washington, D.C.: Georgetown University Press, 336-352.

Halliday, M.A.K. (1961): "Categories of the theory of grammar." Word 17(3): 241-292.

. (1977): "Text as semantic choice in social contexts." In T. A. van Dijk and Jonoss Petofi, eds., Grammars and Descriptions: Studies in Text Theory and Text Analysis. Berlin: Walter de Grugter, 176-225.

. (1978): Language as Social Semiotic: The Social Interpretation of Language and Meaning. London: Edward Arnold.

. (1984): "Linguistics in the university: the question of social accountability." In J. E. Copeland, ed., New Directions in Linguistics and Semiotics. Houston, Texas: Rice University Studies, 51-67.

. (1985): "Systemic background." In J. D. Benson and W. Greaves, eds., Systemic Perspectives on Discourse. Volume 1. Norwood, NJ: Ablex, 1-15.

. (2000): "Grammar and daily life." Functional Approaches to Language, Culture and 
Cognition: Papers in Honor of Sydney M. Lamb. Amsterdam: John Benjamins, 221-237.

Halliday, M. A. K. and Christian M.I.M. Matthiessen (1999): Construing Experience through Meaning: A Language-based Approach to Cognition. London: Cassell. . (2004): An Introduction to Functional Grammar. London: Edward Arnold.

Halliday, M.A.K. and Ruquiya Hasan (1985): Language, Context, and Text: Aspects of Language in Social-semiotic Perspective. Geelong, Victoria: Deakin University Press.

Hasan, Ruquiya (1978): "Text in the systemic-functional model." In W. Dressler, ed., Current Trends in Text Linguistics. Berlin: Mouton de Gruyter, 228-246.

. (1979): "On the notion of text." In J. S. Petofi, ed., Text vs. Sentence: Basic Questions of Text Linguistics. Buske: Hamburg.

. (1984a): "Coherence and cohesive harmony." In J. Flood, ed., Understanding Reading

Comprehension: Cognition, Language and the Structure of Prose. Newark: International Reading Association, 181-219.

. (1984b): "The nursery tales as a genre." Nottingham Linguistic Circular 13: 71-102.

(Reprinted in Hasan, Ruquiya. 1996. Ways of Saying: Ways of Meaning. London: Cassell. 51-72). . (1984c): "The structure of the nursery tale: an essay in text typology." In L. Coveri, ed., Linguistica Testuale. Rome: Bulzoni, 95-114.

Leech, Geoffrey (1966): English in advertising. London: Longman.

Lund, J. V. (1947): Newspaper Advertising. New York: Prentice Hall.

Martin, James R. (1985): "Systemic functional linguistics and an understanding of written text.". In B. Bartlett and J. Carr, eds., Proceedings of the 1984 Working Conference on Language in Education. Brisbane: Brisbane College of Advanced Education. . (1992): English Text: System and Structure. John Benjamins: Amsterdam.

Martin, J. R. and David Rose (2007): Working with Discourse: Meaning beyond the Clause. 2nd edition. London: Continuum.

Martin, James R., Christian M.I.M. Matthiessen and Clare Painter (1997): Working with Functional Grammar. London: Edward Arnold.

Matthiessen, Christian M.I.M. (1988): "Organizing text: rhetorical schemas and generic structure potential." MS. University of Sydney.

. (1992): "Interpreting the textual metafunction." In M.Davies and L. Ravelli, eds., Advances in Systemic Linguistics: Recent Theory and Practice. London: Pinter, 37-81.

. (1993): "Register in the round: diversity in a unified theory of register analysis." In Mohsen Ghadessy, ed., Register analysis: theory and practice. London: Pinter, 221-292.

. (1995): Lexicogrammatical Cartography: English Systems. Tokyo: International Language Sciences Publishers.

. (2000): "Narrative register-lexicogrammatical patterns." MS. Department of Linguistics, Macquarie University.

. (2001): "Notes on systemic functional research." MS. Department of Linguistics, Macquarie University.

. (2002): "Lexicogrammar in discourse development: logogenetic patterns of wording." In H. Guowen and W. Zongyan, eds., Discourse and Language Functions. Shanghai: Foreign Language and Research Press, 91-126

. (2003): "Experiential clause grammar: TRANSITIVITY". MS. Department of Linguistics,Macquarie University

. (2004): "Frequency profiles of some basic grammatical systems: an interim report." In S Hunston and G. Thompson, eds., System and Corpus: Exploring Connections. London: Equinox. (Paper presented at The $29^{\text {th }}$ Systemic Functional Linguistics Congress: Systemic Linguistics and 
the Corpus at The University of Liverpool, 15-19 July 2002.

Pavavimol, Chainum (1994): Buddha Commercialism: Media Effects of Buddha Image Advertising on the Attitudes and Beliefs of Buddhists in Buddhism Symbols. M.A. thesis, Chulalongkorn University.

Toolan, Michael (1988): “The language of press advertising.” In G. Ghadessy, ed., Registers of Written English: Situational Factors and Linguistic Features. London: Pinter, 52-65.

Ure, Jean (1989): “Text Typology.” Unpublished paper.

Vestergaard, T. and Schrøder, K. (1985): The language of advertising. Oxford, Blackwell.

Wongsasuluk, Preecha (1993): The Roles of Mass Media in Value Promotion. The Amuletic Buddha Image and the Buddha Image. M.A. thesis, Chulalongkorn University. 